\title{
Driver Exits Burning Semi-Truck and Falls to His Death
}

\section{CASE SUMMARY}

On Friday, June 8, 2015 a 52-year-old semi-truck driver was traveling southbound on a six- lane interstate. He suddenly braked hard and swerved to the right striking the right shoulder of a bridge concrete barrier wall spanning a river. The right gasoline tank on the truck ruptured and caught fire as a result of the friction.

Though there were no direct witnesses, it is believed the driver exited the passenger side window to escape the fire, and fell to his death over the concrete barrier wall. He was discovered by fire fighters 170 feet below the bridge in a steep wooded area. The victim was pronounced dead at the scene.

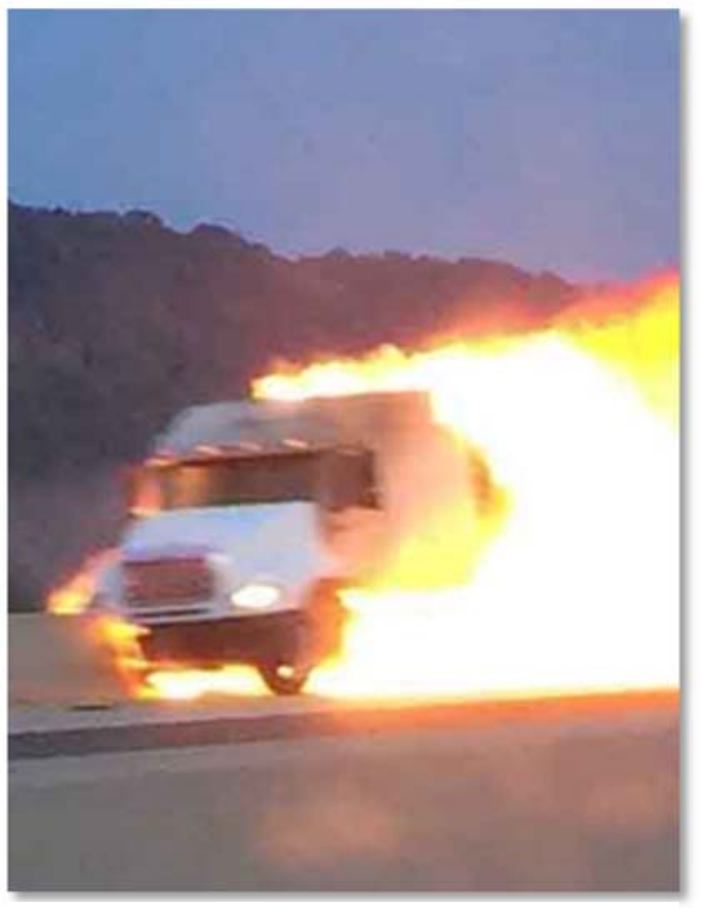

Figure 1. The semi-truck engulfed in flames following the incident.

\section{Recommendations for prevention:}

- Manufacturers should consider the redesign and relocation of fuel tanks on commercial vehicles to reduce risk of penetration and fire.

- $\quad$ Drivers should always be focused on the road to avoid distracted driving.

- Commercial motor vehicle drivers should be trained to know the signs of fatigue and steps to take to eliminate driving while fatigued.

- Employers should ensure that their tractor-trailers are equipped with fire extinguishers. 


\section{EMPLOYER}

The employer was a small trucking company located out of state, with two tractor trailers and two drivers. The employer hauled general freight, fresh produce, refrigerated food and paper products. The company was established July 2, 2014.

\section{SAFETY AND TRAINING PROGRAMS}

The employer did not have any written employee safety programs or provide any training to the two drivers they employed.

\section{VICTIM}

The victim was a 52-year-old high school graduate, who had been employed with the company for 15 years. He moved to the United States from Cuba in 1995 at the age of 32 and worked hard to earn his citizenship. He loved his job because it gave him the opportunity to travel throughout the United States.

\section{INCIDENT SCENE}

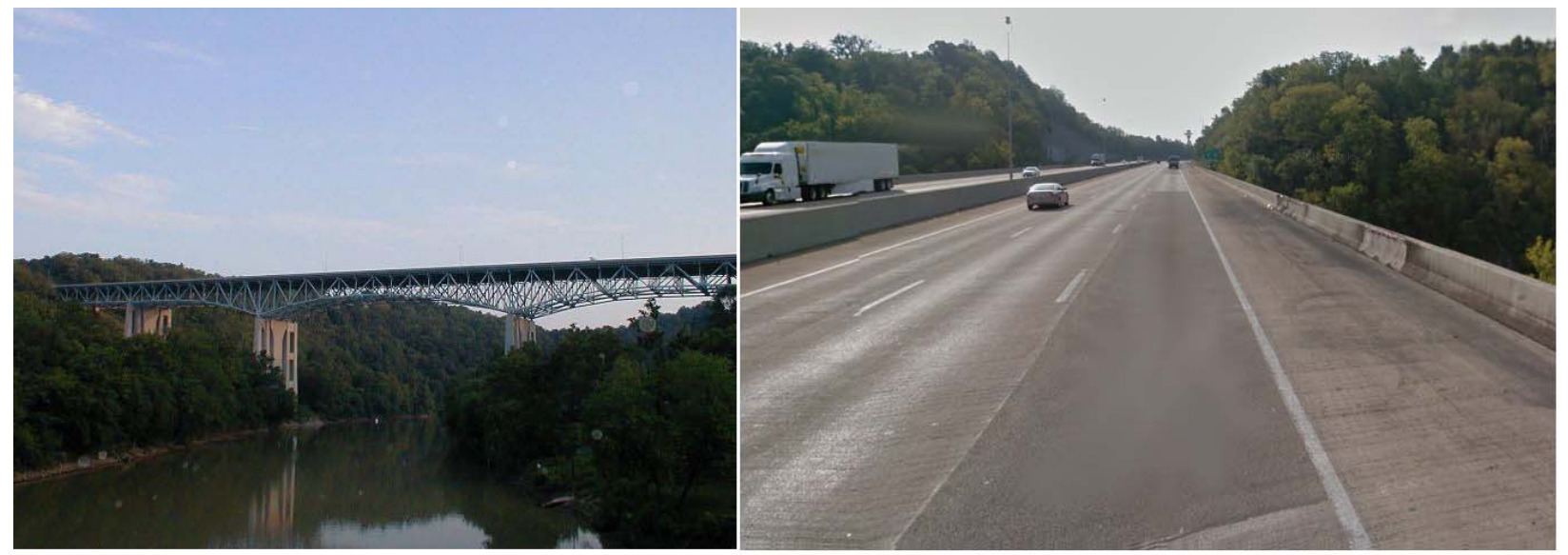

Figure 2. Interstate bridge where the incident occurred.

The incident scene was a southbound six- lane interstate bridge span, 250 feet above a major river. The stretch of roadway was clear and straight with barrier walls on each side and in the middle to divide the interstate. The bridge was lighted for nighttime travel. The tractor trailer was a 2006 Columbia 120 Freightliner.

Although the bridge span was well lit at night, the incident occurred at 6:15 am (dawn) which may have contributed to the driver being unaware of the large drop to the river. 


\section{EQUIPMENT}

The equipment was a 2006 Freightliner Columbia 120 with dual side-mounted fuel tanks, one on each side. This type of design has been shown to make the fuel tank more susceptible to explosion during a collision. The truck was not equipped with a standard fire extinguisher.

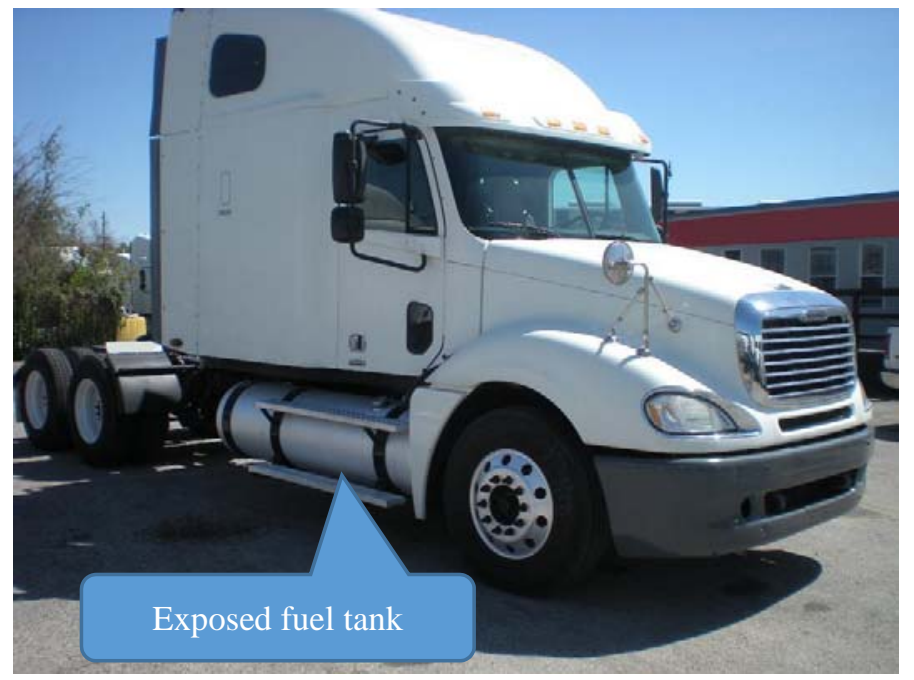

Figure 3. Stock photo of a 2006 Freightliner Columbia 120, similar to the unit involved in this incident.

\section{WEATHER}

June 8, 2015, was a clear day with temperatures ranging from 71 to 80 degrees Fahrenheit. Weather was not considered a factor in this fatality.

\section{INVESTIGATION}

A local news media outlet notified the Kentucky Fatality Assessment and Control Evaluation (FACE) program of a fatality involving a burning tractor-trailer on an interstate bridge. An investigation was conducted.
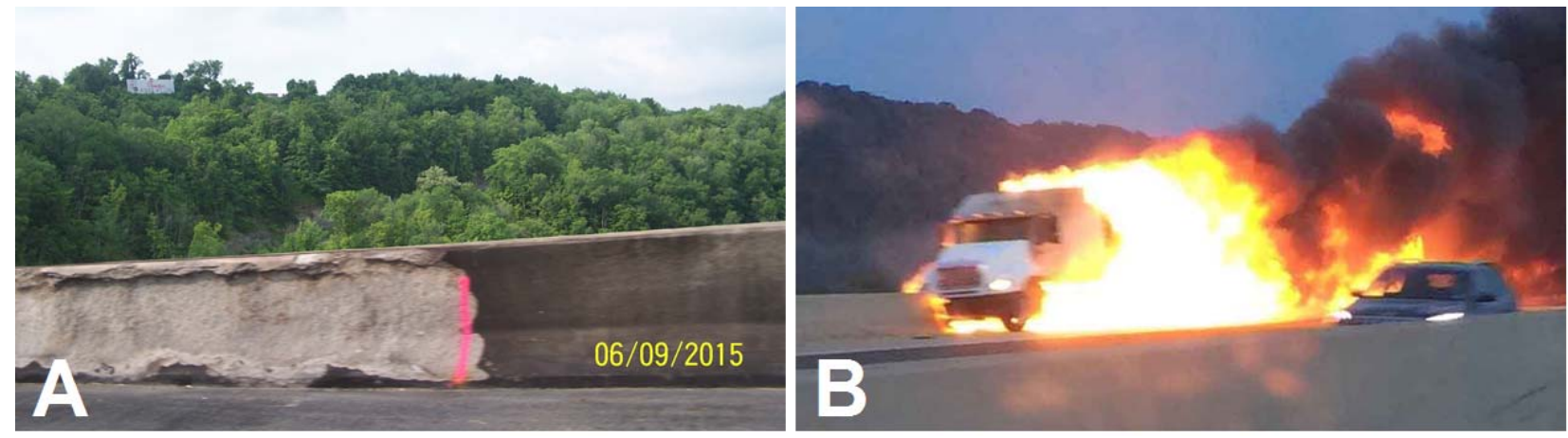

Figure 4. A) Damage to the concrete railing from the semi-truck. B) The semi-truck in flames.

On June 8, 2015, at approximately 6:15 am, a semi-truck driver drove southbound on a major interstate, lost control on a bridge, and struck the right shoulder concrete barrier bridge wall (see 
figure 1). The vehicle rode the top of the barrier, which caused the right fuel tank to rupture and catch fire. The vehicle came to rest several hundred feet down the roadway with the right side leaning over the bridge, continued to burn and then exploded (see figure 5).

Witnesses stated they felt heat from the fire five lanes away. The police arrived 15 minutes later. The southbound lanes were immediately shut down and crews worked quickly to contain the fire. Once the fire was contained, the response team noticed there was no driver inside the cab of the tractor. A team of fire fighters began searching for the driver.

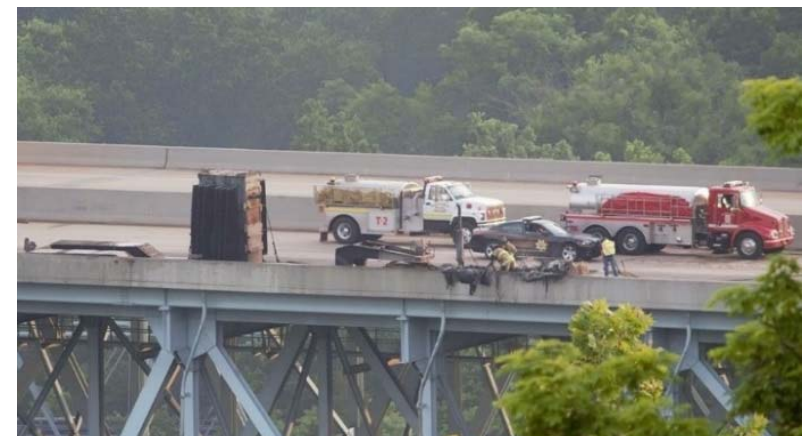

Figure 5. Emergency crews working the scene.

After an extensive search, fire fighters discovered the victim's body 170 feet below the bridge in a steep, wooded area next to the bank of the river (see figure 6A). The victim was pronounced dead at the scene.

It is believed that the truck driver may have panicked, perhaps smelling smoke, and exited the vehicle through the passenger side window after the truck had come to a stop. He may have fallen directly to his death over the barrier wall, or jumped, hoping to escape the fire. It is possible that smoke from the fire obstructed his vision, or that the low dawn light may have contributed to his lack of awareness of the fall hazard.

\section{CAUSE OF DEATH}

The cause of death was multiple blunt force injuries due to falling 170 feet off a bridge onto a steep bank.

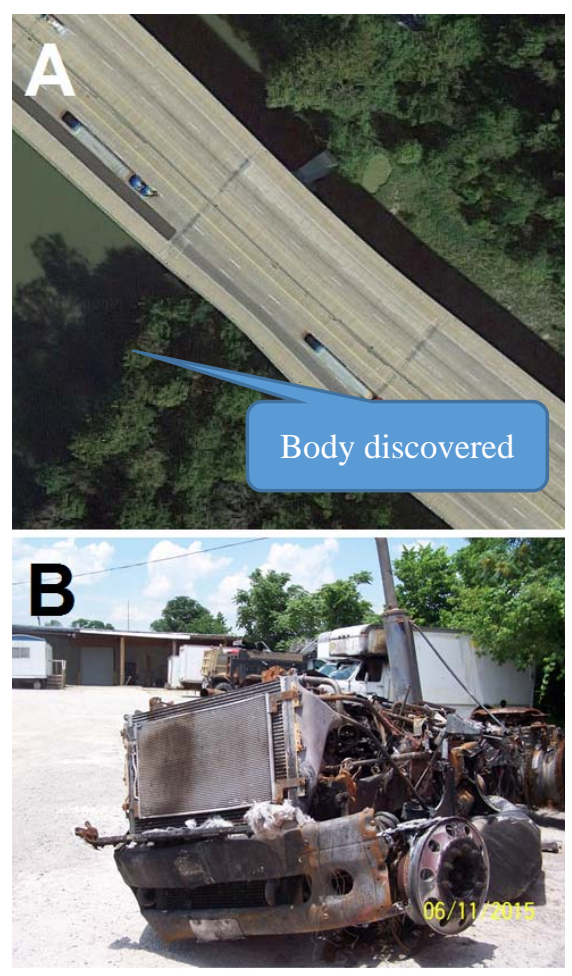

Figure 6. A) Area of woods where the victim was found. B) The charred remains of the semi-truck. 


\section{CONTRIBUTING FACTORS}

Occupational injuries and fatalities are often the result of one or more contributing factors that ultimately result in injury or death. The investigation identified the following factors that may have contributed to the fatality:

- Location of fuel tank resulting in combustion

- Distracted driving (potential)

- Mechanical failure (potential)

\section{RECOMMENDATIONS AND DISCUSSIONS}

Recommendation No. 1: Manufacturers should consider the redesign and relocation of fuel tanks to reduce risk of penetration and fire.

Semi-trucks have two 140 gallon, or greater, diesel fuel tanks, one on each side of the semi. These exposed tanks are at risk for penetration and a resulting fire. A 2012 study of Kentucky motor vehicle collisions found that large trucks are at higher risk for collisions involving fires than passenger cars and pickup trucks. ${ }^{1}$ Manufacturers should consider redesigning and relocating fuel tanks on large commercial vehicles to reduce the risk of penetration and fire. Special attention should be paid to increasing the distance that displaced truck components must traverse before coming into contact with the fuel tanks, and to providing protective barriers between the fuel tanks and the frame of the truck.

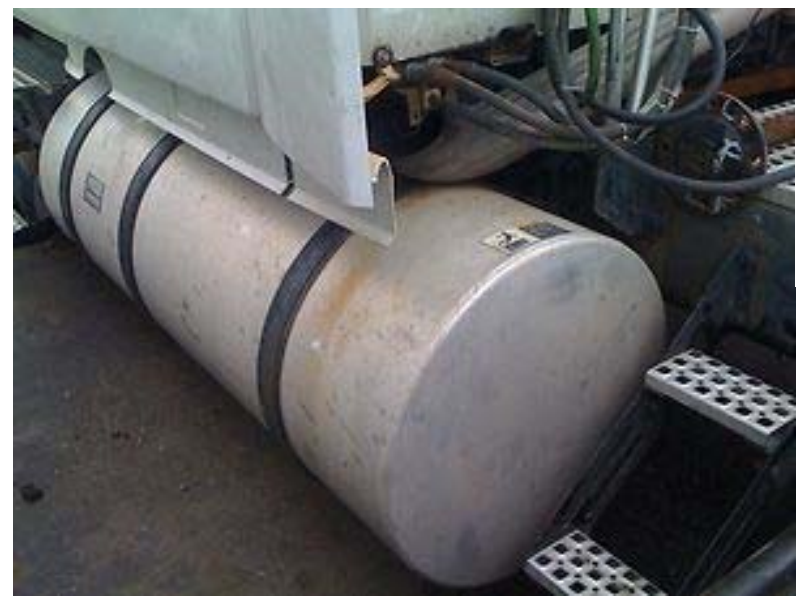

Figure 7. Stock photo of a side mounted fuel tank commonly found in semi-truck designs.

Recommendation No. 2: Drivers should always be focused on the road to avoid distracted driving.

Distracted driving doesn't just include cell phones. Having something on your mind, eating, drinking, smoking and reaching for objects also contribute to driving distracted. ${ }^{2}$ In a split second, drivers can find themselves in a dangerous situation. Focusing on the road ahead 
prevents these situations from occurring. It is unclear why the victim braked and swerved to the right, however, distracted driving could have been a contributing factor.

Recommendation No. 3: Commercial motor vehicle drivers should be trained to know the signs of fatigue and steps to take to eliminate driving while fatigued.

Fatigue could have been a contributing factor to this fatal incident. It is unknown how long the driver had been driving or his origination point. The employer did not answer our inquiries during the fatality investigation. According to the autopsy, the victim did not have any other serious health issues and his toxicology report was negative for drug use.

Recommendation No. 4: Employers should ensure that their tractor trailers are equipped with fire extinguishers. ${ }^{3}$

According to the Federal Motor Carrier Safety Administration (FMCSA) each truck, truck tractor, and bus must be equipped with a class B: C type fire extinguisher and Underwriters Laboratories rating of 10 or more. This type of fire extinguisher is designed to work on electric fires as well as burning liquids. ${ }^{4}$ While a fire of this magnitude could not have been contained with this type of extinguisher, having one on board at all times can help to contain smaller fires and prevent them from spreading and growing.

\section{KEYWORDS}

Distracted driving

Trucking hazards

Trucking fires

Trucking accidents

\section{OTHER RESOURCES}

KY FACE Report: Semi Tractor-Trailer Driver Dies in Median Crossover Crash; 10 Others Die (10KY008). [http://www.mc.uky.edu/kiprc/projects/KOSHS/face/data/Reports/10KY008.pdf]

\section{REFERENCES}

${ }^{1}$ Bunn, T.L., Slavova, S., Robertson, M. (2012). Crash and burn? Vehicle, collision, and driver factors that influence motor vehicle collision fires. Accident Analysis and Prevention, 47, 140150. doi: 10.1016/j.aap.2011.10.008. [http://www.ncbi.nlm.nih.gov/pubmed/22405242]

${ }^{2}$ Distracted driving- National Safety Council

[http://www.nsc.org/lean/.../distracted]

${ }^{3}$ Parts and Accessories Necessary for Safe Operation- Emergency equipment on all power units Federal Motor Carrier Safety Administration 
[http://www.fmcsa.dot.gov/regulations/title49/section/393.95]

${ }^{4}$ Fire Prevention. Trucking Truth

[http://www.truckingtruth.com/cdl-training-program/page31]

\section{PHOTO CREDIT}

Photos used were taken by the Kentucky FACE program and WLEX news. Aerial depiction of the scene used in photo 6A is credited to Google Maps.

\section{ACKNOWLEDGEMENTS}

The Kentucky FACE program would like to thank the State Highway Patrol and the fire department for their assistance with this report.

\section{PROGRAM FUNDING}

The Kentucky Fatality Assessment \& Control Evaluation Program (FACE) is funded by grant 2U60OH008483-11 from the Centers for Disease Control and Prevention and the National Institute for Occupational Safety and Health.

Please take the time to complete our brief survey regarding this report:

(https://uky.az1.qualtrics.com/jfe/form/SV_dppb56kqUaGEFYp)

Electronic access to this full report can be found here:

(http://www.mc.uky.edu/kiprc/programs/face/files/15KY030.pdf)

FACE on Social Media:

https://www.facebook.com/Kentucky-FACE-Program$\underline{134135740092906 / \text { ?view_public for }=134135740092906}$

http://www.twitter.com/KYFACEProgram 
This case report was developed by the Kentucky Fatality Assessment and Control Evaluation (FACE) Program. Kentucky FACE is a NIOSH-funded occupational fatality surveillance program with a goal of preventing fatal work injuries by studying the worker, the work environment, and the role of management, engineering, and behavioral changes in preventing future injuries. The FACE Program is located within the Kentucky Injury Prevention and Research Center (KIPRC), part of the University of Kentucky's College of Public Health.

Email: kyfaceprogram@uky.edu | Telephone: 859-257-5839 333 Waller Avenue Suite 242, Lexington, KY 40504 